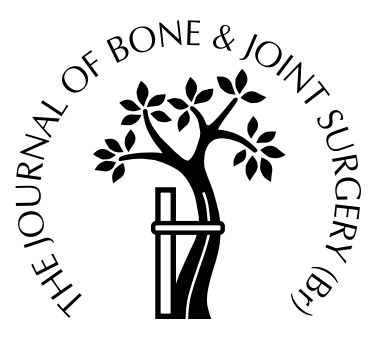

\title{
Treatment of nonunion around the olecranon fossa of the humerus by intramedullary locked nailing
}

\author{
Odathurai N. Paramasivan, Derek A. Younge, Rajeev Pant \\ From the King Faisal Specialist Hospital and Research Centre, Riyadh, Saudi Arabia
}

\begin{abstract}
Nonunion of fractures of the olecranon fossa of the humerus presents a difficult surgical problem. The distal fragment is usually small and osteoporotic and stable fixation is not easy to achieve. We describe a modification of the technique of locked nailing by which the distal aspect of the nail is placed in the subchondral region of the trochlea. Good results were obtained in seven out of eight patients with this technique.
\end{abstract}

J Bone Joint Surg [Br] 2000;82-B:332-5.

Received 11 September 1998; Accepted after revision 6 October 1999

Ununited fractures of the distal humerus are often painful and unstable, and there may be considerable functional disability. Satisfactory surgical management is difficult. ${ }^{1,2}$ Fixation with a plate and bone grafting may give satisfactory results if there is sufficient bone stock, ${ }^{3-5}$ but this technique may fail. ${ }^{6,7}$ The outcome of revision surgery may be adversely affected by stiffness of the elbow, scarring from previous surgery and the fact that the distal fragment is small and osteoporotic. ${ }^{2,4,8}$

Neither arthrodesis of the elbow nor excision arthroplasty is a satisfactory salvage procedure. ${ }^{4,6,9,10}$ Despite some good results in elderly patients ${ }^{6}$, elbow arthroplasty is not suitable for the treatment of post-traumatic conditions because of the high incidence of loosening of the humeral component. ${ }^{4,11-14}$ The long-term results of cadaver elbow allografts are not known. ${ }^{7,10}$ Satisfactory placement of the pin in the small distal fragment is difficult when external

O. N. Paramasivan, FRCS Ed, Consultant Orthopaedic Surgeon

D. A. Younge, FRCS C, Consultant Orthopaedic Surgeon

R. Pant, FRCS Ed (Orth), Assistant Consultant Orthopaedic Surgeon

Department of Orthopaedic Surgery-MBC 77, King Faisal Specialist

Hospital and Research Centre, PO Box 3354, Riyadh 11211, Saudi Arabia.

Correspondence should be sent to Dr O. N. Paramasivan at the Trauma and Orthopaedic Unit, Kovai Medical Centre and Hospitals, PO Box 3209, Avinashi Road, Coimbatore 641014, India.

(C)2000 British Editorial Society of Bone and Joint Surgery 0301-620X/00/39474 \$2.00

332 fixators are used. Revision surgery with double or triple plating has the risks of further devitalisation and avascular necrosis of the distal fragment. ${ }^{5}$ The intramedullary locked nail is gaining acceptance for the treatment of fractures and nonunion of the shaft of the humerus, ${ }^{15-20}$ but it has not been recommended for supracondylar lesions since the end of the medullary canal is proximal to the olecranon fossa. $^{16}$

\section{Patients and Methods}

Between March 1995 and September 1996 we treated eight patients aged from 20 to 62 years who had nonunion around the region of the olecranon fossa, seven following fracture and one after osteotomy for cubitus varus after a supracondylar fracture. One patient (case 2) developed nonunion after pathological fracture following biopsy of an eosinophilic granuloma. Table I gives the details of the patients. Four had marked stiffness of the joint and four gross instability (Fig. 1). At least one, and in most cases two previous attempts at internal fixation and bone grafting had failed.

Operative technique. We use a transolecranon approach to the distal humerus. The ulnar nerve is exposed and protected as is the radial nerve for the more proximal cases. Previous implants are removed. Arthrolysis of the elbow is performed as described by Morrey. ${ }^{21}$ A $3.2 \mathrm{~mm}$ drill is used to perforate the trochlear notch and advanced proximally across the olecranon fossa into the intramedullary canal. A guide wire is introduced in an antegrade fashion from the shoulder to the elbow (Fig. 2). The canal is then reamed with a flexible reamer which is passed across the site of nonunion and the olecranon fossa under direct vision and stopped just before the articular cartilage. An intramedullary humeral nail (Biomet Inc, Warsaw, Indiana) of appropriate length is inserted in an antegrade manner after removal of the distal $8 \mathrm{~mm}$ of the nail. This allows the distal locking to be performed at the widest condylar area (Fig. 3). The screws supplied are too short for this site, and we therefore use $4.5 \mathrm{~mm}$ AO cortical screws. Proximal locking is performed in the usual manner and autogenous cancellous bone graft is added. The olecranon is reattached. Active mobilisation of the elbow without splintage is encouraged after operation. 


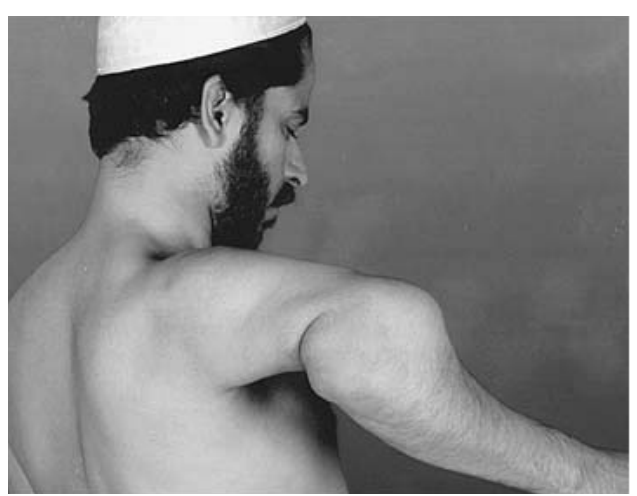

Fig. 1a

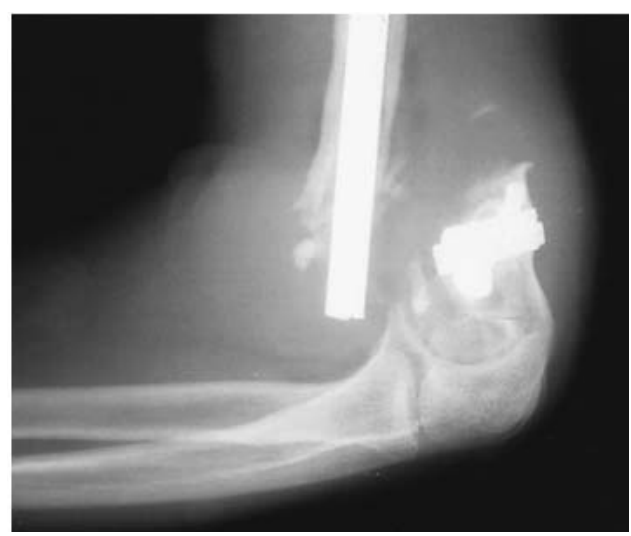

Fig. 1c

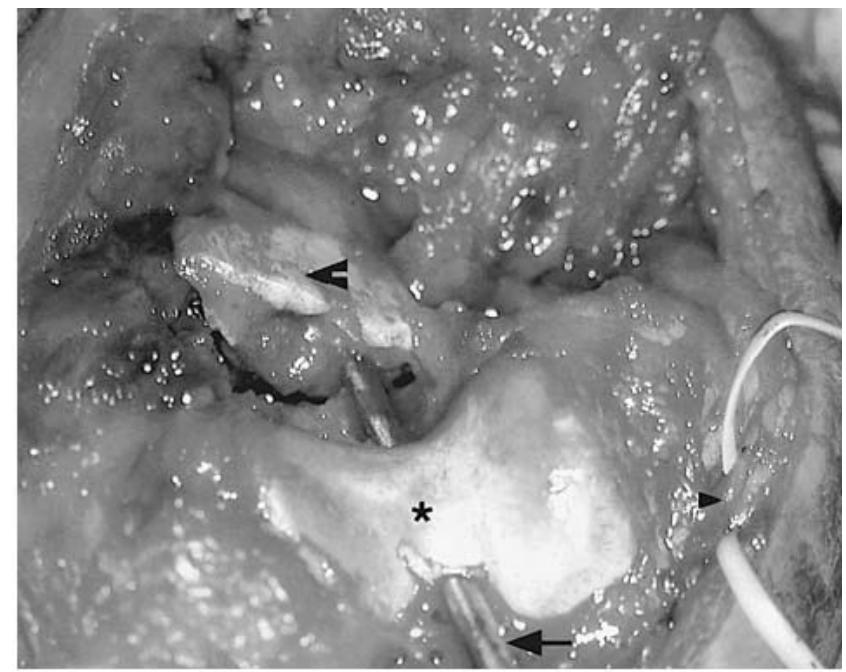

Fig. 2

Photograph showing the guide wire passing through the olecranon fossa $(\boldsymbol{\rangle}$, ulnar nerve; $\rightarrow$, guide wire; $\boldsymbol{>}$, proximal fragment; and $*$, trochlea (distal fragment).

\section{$\underline{\text { Results }}$}

Seven of the eight patients achieved bony union (Fig. 4) and improvement of movement of the elbow (Table I). One patient (case 3) with considerable associated soft-tissue and

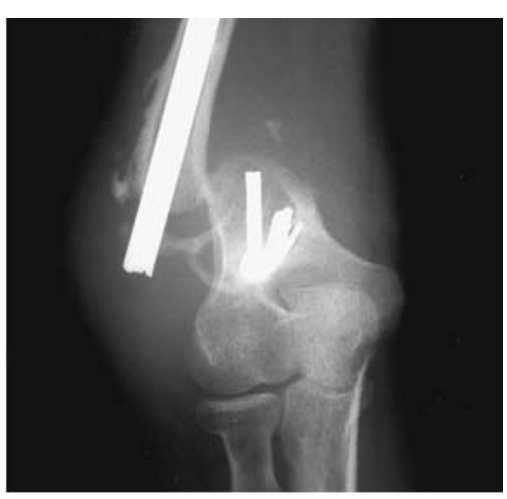

Fig. 1b

Case 7. Figure 1a - Photograph showing the unstable upper limb. Figures $1 \mathrm{~b}$ and $1 \mathrm{c}-$ Anteroposterior (b) and lateral (c) radiographs of the elbow before operation showing non-union and the broken Siedel nail.

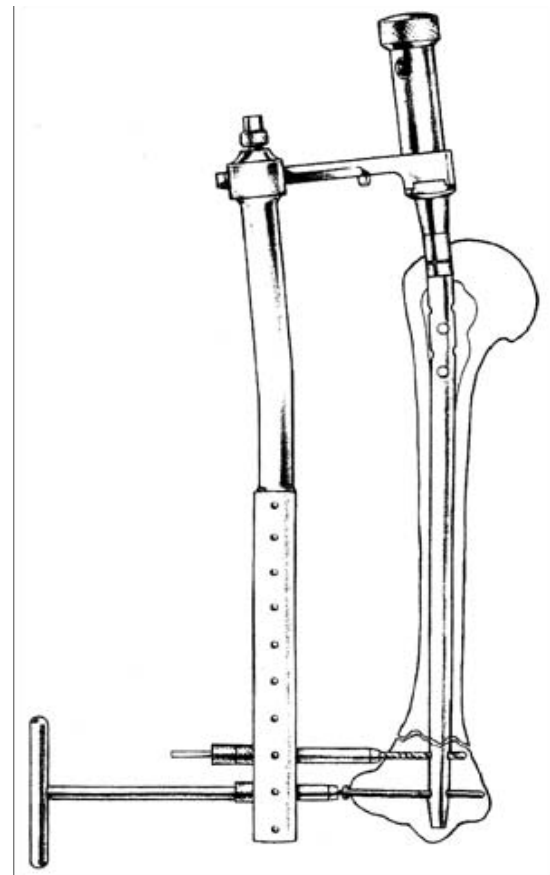

Fig. 3

Diagram of the intramedullary nail with the target device to show the position of the two distal locking screws in the widest condylar area.

neurovascular damage (Gustilo IIIB) has a stiff elbow with only a 'jog' of movement, but is painfree. Two patients required further bone-grafting and one of these has persistent nonunion. There were no other complications except for a broken screw (case 6). 


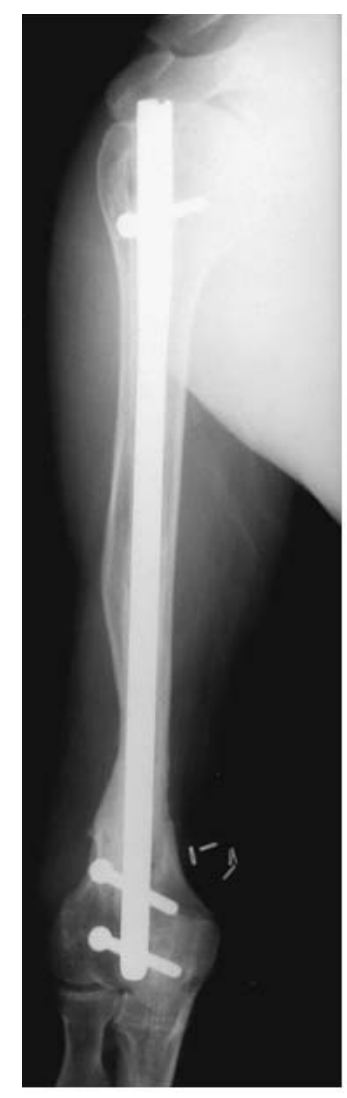

Fig. 4a

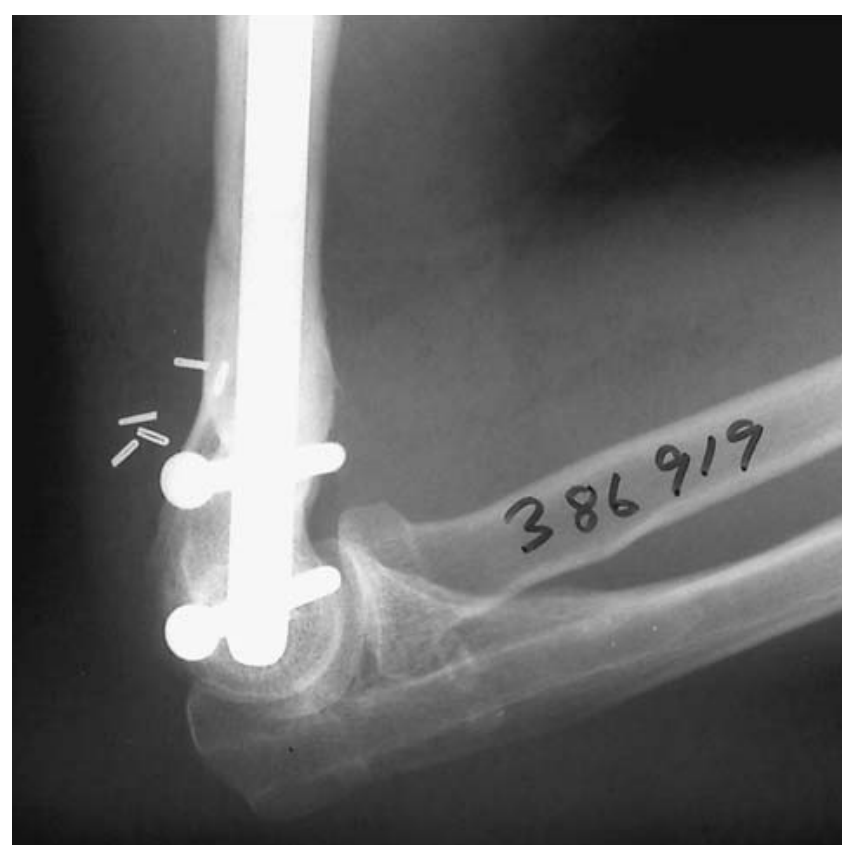

Fig. 4b

Case 7. Anteroposterior (a) and lateral (b) radiographs at 22 months showing solid bony union.

Table I. Details of the eight patients with nonunion of the olecranon fossa

\begin{tabular}{|c|c|c|c|c|c|c|c|c|c|c|c|c|}
\hline \multirow[b]{2}{*}{ Case } & \multirow{2}{*}{$\begin{array}{l}\text { Age } \\
(\mathbf{y r})\end{array}$} & \multirow[b]{2}{*}{ Gender } & \multirow[b]{2}{*}{ Cause } & \multirow[b]{2}{*}{$\begin{array}{l}\text { Previous } \\
\text { surgery }\end{array}$} & \multirow[b]{2}{*}{ Symptoms } & \multirow[b]{2}{*}{$\begin{array}{l}\text { Duration } \\
\text { (yrs) }\end{array}$} & \multicolumn{2}{|c|}{$\begin{array}{l}\text { Range of elbow } \\
\text { movement (degrees) }\end{array}$} & \multirow[b]{2}{*}{$\begin{array}{l}\text { Follow-up } \\
\text { (mth) }\end{array}$} & \multirow[b]{2}{*}{$\begin{array}{l}\text { Nonunion } \\
\text { healed }\end{array}$} & \multirow[b]{2}{*}{$\begin{array}{l}\text { Fixation } \\
\text { failure }\end{array}$} & \multirow[b]{2}{*}{$\begin{array}{l}\text { Number of } \\
\text { bone grafts }\end{array}$} \\
\hline & & & & & & & Preop & Postop & & & & \\
\hline 1 & 56 & $\mathrm{~F}$ & Fall & $\begin{array}{l}\text { DCP plate } \\
3 \text { attempts }\end{array}$ & $\begin{array}{l}\text { Pain } \\
\text { Stiffness }\end{array}$ & 5 & 45 to 60 & 0 to 130 & 41 & Yes & No & 1 \\
\hline 2 & 23 & M & $\begin{array}{l}\text { Biopsy } \\
\text { (eosinophilic } \\
\text { granuloma) }\end{array}$ & $\begin{array}{l}\text { DCP plate } \\
3 \text { attempts }\end{array}$ & $\begin{array}{l}\text { Pain } \\
\text { Stiffness }\end{array}$ & 5 & 45 to 90 & 0 to 130 & 39 & Yes & No & 1 \\
\hline 3 & 20 & M & $\begin{array}{l}\text { RTA* } \\
\text { Compound fracture } \\
\text { Neurovascular damage }\end{array}$ & $\begin{array}{l}\text { DCP \& recon } \\
\text { plates } \\
2 \text { attempts }\end{array}$ & $\begin{array}{l}\text { Instability } \\
\text { Pain }\end{array}$ & 3 & $\begin{array}{l}\text { FFD } \uparrow 90 \\
\text { Nil }\end{array}$ & 80 to 90 & 39 & Yes & No & 2 \\
\hline 4 & 62 & $\mathrm{~F}$ & Fall & $\begin{array}{l}\text { Two } \\
1 / 3 \text { tubular } \\
2 \text { attempts }\end{array}$ & $\begin{array}{l}\text { Pain } \\
\text { Stiffness }\end{array}$ & 3 & 45 to 60 & 15 to 130 & 36 & Yes & No & 1 \\
\hline 5 & 50 & $\mathrm{~F}$ & Fall & $\begin{array}{l}\text { Two recon } \\
\text { plates } \\
1 \text { attempt }\end{array}$ & $\begin{array}{l}\text { Pain } \\
\text { Instability }\end{array}$ & 2 & 45 to 80 & 30 to 130 & 36 & Yes & No & 1 \\
\hline 6 & 20 & M & Osteotomy & $\begin{array}{l}\text { Screw and wire } \\
1 \text { attempt }\end{array}$ & $\begin{array}{l}\text { Gross } \\
\text { instability }\end{array}$ & 8 & Nil & 0 to 90 & 22 & No & Yes & 2 \\
\hline 7 & 38 & M & RTA & $\begin{array}{l}\text { Siedel nail } \\
1 \text { attempt }\end{array}$ & $\begin{array}{l}\text { Gross } \\
\text { instability }\end{array}$ & 2 & Nil & 0 to 120 & 22 & Yes & No & 1 \\
\hline 8 & 36 & M & Fall & $\begin{array}{l}2 \text { plates } \\
2 \text { attempts }\end{array}$ & $\begin{array}{l}\text { Pain } \\
\text { Stiffness }\end{array}$ & 2 & $\begin{array}{l}\text { FFD } 45 \\
\text { Nil }\end{array}$ & 45 to 90 & 22 & Yes & No & 1 \\
\hline
\end{tabular}

* road-traffic accident

$\dagger$ fixed flexion deformity 


\section{Discussion}

Bone grafting and plating are an accepted method of managing supracondylar nonunion in the humerus, ${ }^{5}$ but a significant percentage of patients $(27 \%)$ requires further procedures. ${ }^{3}$ All our patients had had one or more previous attempts at fixation. Jupiter and Goodman ${ }^{5}$ advocated triple plating, bone grafting and elbow arthrolysis and reported good results in five out of six patients but with one case of avascular necrosis. Total elbow arthroplasty has been used to treat nonunion of fractures of the distal humerus, but Mitsunaga et $\mathrm{al}^{13}$ and Figgie et $\mathrm{al}^{4}$ reported unsatisfactory results. Morrey and Adams ${ }^{6}$ found total elbow replacement to be a valuable operation in elderly patients but emphasised that it is not appropriate for younger patients or for post-traumatic conditions. Our technique of intramedullary locked nailing is a suitable method of treatment for this problem particularly in younger patients.

Fixation using an intramedullary locked nail is biomechanically superior to that with a plate, ${ }^{22}$ but it has not been considered suitable for the supracondylar region because the medullary canal ends proximal to the olecranon fossa. Using our technique, it is possible to create a track which allows the nail to be seated as far distally as the subchondral region of the trochlea. The most distal locking screw is placed in the widest condylar area and this construct, combined with elbow arthrolysis, may restore movement of the elbow. In three patients the distal fragment was slightly extended (Fig. 4b).

We gratefully acknowledge Dr P. G. Moreau, Chairman, Department of Orthopaedic Surgery, King Faisal Specialist Hospital and Research Centre for permitting us to include his patients in this study, and the secretarial assistance of Ms V. G. Lector.

No benefits in any form have been received or will be received from a commercial party related directly or indirectly to the subject of this article.

\section{References}

1. Horne G. Supracondylar fractures of the humerus in adults. $J$ Trauma 1980;20:71-4.

2. Müller ME, Allgöwer M, Schneider R, Willenegger H. Manual of internal fixation: techniques recommended by the AO group. Second ed. Berlin, etc: Springer-Verlag, 1979.

3. Ackerman G, Jupiter JB. Nonunion of fractures of the distal end of the humerus. J Bone Joint Surg [Am] 1988;70-A:75-83.
4. Figgie MP, Inglis AE, Mow CS, Figgie HE III. Salvage of non-union of supracondylar fracture of the humerus by total elbow arthroplasty. J Bone Joint Surg [Am] 1989;71-A:1058-65.

5. Jupiter JB, Goodman LJ. The management of complex distal humerus nonunion in the elderly by elbow capsulectomy, triple plating, and ulnar nerve neurolysis. $J$ Shoulder Elbow Surg 1992;1:37-46.

6. Morrey BF, Adams RA. Semiconstrained elbow replacement for distal humeral nonunion. J Bone Joint Surgery [Br] 1995;77-B:6772.

7. Urbaniak JR, Black KE Jr. Cadaveric elbow allografts: a six-year experience. Clin Orthop 1985;197:131-40.

8. McKee MD, Jupiter J, Toh CI, et al. Reconstruction after malunion and nonunion of intra-articular fractures of the distal humerus: methods and results in 13 adults. J Bone Joint Surg [Br] 1994;76-B:61421.

9. Beckenbaugh RD. Resectional arthroplasty and arthrodesis of the elbow. In: Evarts CM, ed. Surgery of the musculoskeletal system. New York, etc: Churchill Livingstone, 1983:3:265-272.

10. Dee R. Reconstructive surgery following total elbow endoprosthesis. Clin Orthop 1982;170:196-203.

11. Inglis AE, Pellicci PM. Total elbow replacement. J Bone Joint Surg [Am] 1980;62-A:1252-8.

12. Kraay MJ, Figgie MP, Inglis AE, Wolfe SW, Ranawat CS. Primary semiconstrained total elbow arthroplasty: survival analysis of 113 consecutive cases. J Bone Joint Surg [Br] 1994;76-B:636-40.

13. Mitsunaga MM, Bryan RS, Linscheid RL. Condylar nonunions of the elbow. J Trauma 1982;22:787-91.

14. Morrey BF, Bryan RS, Dobyns JH, Linscheid RL. Total elbow arthroplasty: a five-year experience at the Mayo Clinic. J Bone Joint Surg [Am] 1981;63-A:1050-63.

15. Kellam JF. Interlocking nail fixation for humeral shaft fractures. Operative techniques in orthopaedics 1991;1:336-46.

16. Redmond BJ, Biermann JS, Blasier RB. Interlocking intramedullary nailing of pathological fractures of the shaft of the humerus. $J$ Bone Joint Surg [Am] 1996;78-A:891-6.

17. Rommens PM, Verbruggen J, Broos PL. Retrograde locked nailing of humeral shaft fractures: a review of 39 patients. J Bone Joint Surg [Br] 1995;77-B:84-9.

18. Ward FE, White JL. Interlocked intramedullary nailing of the humerus. Orthopedics 1989;12:135-41.

19. Jensen CH, Hansen D, Jorgensen U. Humeral shaft fractures treated by interlocking nailing: a preliminary report on 16 patients. Injury 1992;23:234-6.

20. Ingman AM, Waters DA. Locked intramedullary nailing of humeral shaft fractures: implant design, surgical technique and clinical results. J Bone Joint Surg [Br] 1994;76-B:23-9.

21. Morrey BF. Post-traumatic contracture of the elbow: operative treatment including distraction arthroplasty. J Bone Joint Surg [Am] 1990;72-A:601-18.

22. Zimmerman MC, Waite AM, Dohan M, Jovey J, Coppenheim W. A biomechanical analysis of four humeral fracture fixation systems. $J$ Orthop Trauma 1994;8:233-9. 